\title{
MEMBANGUN KERUKUNAN MELALUI KONSEP ESOTERISME DALAM TEKS TUTUR JATISWARA (STUDI FILSAFAT PERENNIAL)
}

Oleh :

I Komang Suastika Arimbawa*

\begin{abstract}
Religion is one of the sub parts that becomes the 'spotlight'when there is widespread conflict and violence. This is due to the displacement of spirituality-esoteric aspects in modern human life, so that in reality it is often found distortions of human values. In addition, the dynamics of community understanding are also still doctrinal and filled with the content of exclusivity in responding to plurality, as well as the erosion of respect for responding to horizontal conflicts. For this reason, the concept of esotericism in the text of Tutur Jatiswara is believed to be able to provide a theo-philosophical solution and build an inclusive-pluralist paradigm, and can be one of the guidelines for realizing a harmonious, peaceful and mutual assistance in helping joy and sorrow.

Perennial Philosophy is seen as able to explain all the events that are essential, concerning the wisdom needed in carrying out the right life, which seems to be the essence or core of all major religions and traditions of human spirituality. This fact is the basis for the statement that all religions are the same in the esoteric area. There is no superior religion among other religions, because basically all religions are accommodating the "Truth and Absolute" of the One.
\end{abstract}

Keywords: harmony, esotericism, the text of Tutur Jatiswara, perennial philosophy.

\section{ABSTRAK}

Agama adalah salah satu sub bagian yang menjadi 'sorotan' ketika terjadi konflik dan kekerasan yang meluas. Hal ini disebabkan oleh perpindahan aspek spiritual-esoterik dalam kehidupan manusia modern, sehingga pada kenyataannya sering ditemukan distorsi nilai-nilai kemanusiaan. Selain itu, dinamika pemahaman masyarakat juga masih bersifat doktrinal dan diisi dengan konten eksklusivitas dalam merespons pluralitas, serta erosi rasa hormat untuk merespons konflik horizontal. Untuk alasan ini, konsep esoterisme dalam teks Tutur Jatiswara diyakini dapat

*) I Komang Suastika Arimbawa, S.Ag., M.Ag., adalah staf pengajar di lingkungan Fakultas Brahma Widya IHDN Denpasar 
memberikan solusi theo-filosofis dan membangun paradigma inklusif-pluralis, dan dapat menjadi salah satu pedoman untuk mewujudkan bantuan yang harmonis, damai dan saling menguntungkan. dalam membantu suka dan duka.

Filsafat Perenial dipandang dapat menjelaskan semua peristiwa yang penting, menyangkut kebijaksanaan yang diperlukan dalam menjalankan kehidupan yang benar, yang tampaknya merupakan esensi atau inti dari semua agama besar dan tradisi spiritualitas manusia. Fakta ini menjadi dasar pernyataan bahwa semua agama adalah sama di wilayah esoterik. Tidak ada agama yang unggul di antara agama-agama lain, karena pada dasarnya semua agama mengakomodasi "Kebenaran dan Mutlak" dari Yang Satu.

Kata kunci: harmoni, esoterisme, teks Tutur Jatiswara, filsafat abadi.

\section{PENDAHULUAN}

Agama di kalangan masyarakat diyakini dapat mendatangkan rasa aman dan tentram dalam kehidupannya, serta dapat mengantarkan dan menuntun umat manusia menuju kebahagiaan hidup jasmani maupun rohani. Selain itu, agama juga berisi petunjuk serta tuntunan hidup yang paling memadai untuk manusia dalam menjalani kehidupannya di dunia ini.

Manusia yang berasal dari berbagai suku, ras, etnis dan bangsa yang berbeda-beda meyakini keberadaan agama. Itulah yang menjadikan keagamaan sering muncul dalam 'wajahnya' yang plural, layaknya bangunan sebuah rumah yang terdiri dari beberapa kamar. Setiap kamar memiliki kekhasannya masing-masing, dengan berbagai tampilan dekorasi interior, bentuk, dan perlengkapan yang beragam, namun pada esensinya memiliki fungsi yang sama. Demikian juga halnya dengan agama, yang secara eksoterik menampakkan perbedaannya, tetapi secara esoterik tujuannya sama. Manusia sebagai pengguna 'kamar' tersebut, mempunyai kebebasan sepenuhnya untuk 'menghuni' kamar sesuai dengan kenyamanan hati pribadinya masing-masing.

Namun, dalam perkembangan kehidupan beragama di masyarakat, tidak bisa dipungkiri bahwa gesekan-gesekan dengan latar belakang agama (konflik agama) masih sering terjadi. Hal inilah yang menjadi tantangan besar dalam kehidupan masyarakat, termasuk bagi keberagamaan. Gesekan-gesekan yang terjadi bahkan tidak menutup kemungkinan sampai berujung pada kekerasan, baik dalam bentuk kekerasan fisik maupun kekerasan psikis. Baik dalam skala kecil, tingkat lingkungan, desa, bahkan antar-etnis. Hal ini menunjukkan bahwa kekerasan sudah semakin akrab dengan kehidupan di masyarakat. Semua fenomena kekerasan 
tersebut sangat membutuhkan "kehadiran" agama dalam pemecahannya.

Akan tetapi, mengingat bahwa agama merupakan salah satu sub yang ikut menjadi 'sorotan' ketika kekerasan muncul di beberapa wilayah, pemahaman keberagamaan tentang perbedaan dan keragaman divonis sangat rendah. Oleh sebab itu, harus diadakan rekonstruksi konsep pemikiran yang memanusiakan manusia. Kenapa demikian? Karena dalam realitas kehidupan sering ditemukan anggota masyarakat dalam menempuh kehidupannya terjadi distorsi-distorsi nilai kemanusiaan. Terjadinya dehumanisasi disebabkan oleh kapasitas intelektual dan mental yang tidak siap untuk mengarungi samudera kehidupan di era global. Ketidakberdayaan manusia 'bermain' dalam pentas kehidupan yang terus melaju, menyebabkan sebagian masyarakat terperangkap dalam "jala” kehidupan. Perasaan resah senantiasa 'menghantui' kehidupannya akibat perubahan sosial yang berlangsung sangat cepat, interaksi sosial yang semakin menggersang, serta perubahan stabilitas sosial menjadi mobilitas sosial.

Disisi lain, terdapat masyarakat modern yang memiliki paham fanatis, duplikatif serta tidak akomodatif sehingga masyarakat seperti ini tidak siap menghadapi realitas kehidupan (pergeseran nilai) dalam aspek ideologi, sosialbudaya, politik, ekonomi, dan sebagainya yang dipandangnya tepat dalam konteks keagamaan (Zurqoni dan Muhibat, 2011: 36).

Dalam beberapa tahun terakhir, terjadi berbagai kasus konflik dan kekerasan; seperti radikalisme fundamental yang merupakan gejala sosial dan keagamaan laten yang sejak dua dekade terakhir tampak menguat dalam beragam bentuk, antara lain: penolakan FUI (Forum Umat Islam) Bima terhadap keberadaan Pura Jagad Agung Tambora, insiden pembakaran mushala di Tolikara, insiden penembakan/pembunuhan sadis atas nama agama di Charlie Hebdo, dan lain-lain. Kekerasan demi kekerasan yang dilakukannya itu, bukan saja dapat mengganggu kebebasan umat beragama dalam menunaikan ajaran agamanya, tetapi juga dapat mencederai dan menodai sendi-sendi ajaran agama itu sendiri. Keadaan ini pada gilirannya akan menghancurkan hak-hak heterogenitas (keragaman) dan memporak-porandakan kesatuan bangsa (Shofan, 2011: 37).

Selain itu, terdapat konflik-konflik lain yang mengatasnamakan agama, seperti banyaknya situs-situs di internet yang berbau SARA, hingga kasus-kasus pelabelan "sesat", "kafir", dan sebagainya terhadap seseorang maupun aliran atau sempalan keagamaan, sehingga berdampak pada aksi "penghakiman" terhadap orang atau kelompok yang dicap menyimpang. Kejadiankejadian tersebut menunjukkan telah terjadinya proses dehumanisasi terhadap kemanusiaan yang seharusnya dijunjung tinggi harkat dan martabatnya.

Fenomena sosial ini menunjukkan terjadinya kesenjangan yang tajam antara agama dalam kitab suci dengan agama dalam masyarakat. Jika agama mengajarkan cinta kasih, perdamaian, kejujuran, menghargai pluralisme untuk memperkaya spiritualitas serta tolong menolong 
dalam kebajikan dan taqwa, beda halnya dengan institusi agama yang sering terlibatkan dalam suasana saling merendahkan, saling memusuhi, saling mencurigai dan melakukan kekejaman (Dermawan, 2009: 51).

Ada kalangan-kalangan tertentu menilai bahwa konflik dengan latar belakang SARA yang sering terjadi di Indonesia merupakan akibat dari ketidakmampuan pemerintah dalam menyediakan kebutuhan ekonomi dan menyenggarakan keamanan Negara. Namun apabila kita mencermati dan memahami kembali perilaku para pemeluk agama, nampaknya bukan agamalah yang menjadi 'biang kerok' disharmoni dalam kehidupan beragama masyarakat, melainkan para 'oknum' pemeluk agamalah yang menggunakan gaya eksklusif dan persepsi 'ego' mereka sendiri dalam menerjemahkan ajaran agamanya. Sehingga dengan gaya yang demikian akan melahirkan suatu anggapan yang menjelma sebagai 'keyakinan' bahwa agamanyalah yang paling benar, yang paling tepat, serta yang paling unggul diantara agama-agama lainnya.

Pada hakikatnya agama berperan sebagai pedoman hidup manusia. Agama diyakini dapat menunjukkan kepada manusia mengenai kebenaran. Setiap ajaran agama menghendaki umatnya agar mampu mewujudkan ketentraman dan keharmonisan dalam hidupnya, sebagaimana dalam ajaran agama Hindu diwujudkan dengan tercapainya keharmonisan meliputi tiga hal yang disebut dengan Tri Hita Karana, yaitu hubungan yang harmonis antara manusia dengan Tuhan (parahyangan), hubungan yang harmonis antara manusia dengan sesamanya (pawongan), serta hubungan yang harmonis antara manusia dengan lingkungannya (palemahan). Ketiga hubungan tersebut mampu mewujudkan kedamaian dan ketentraman dalam kehidupan manusia.

Agama dalam kehidupan individu berfungsi sebagai suatu sistem nilai yang memuat normanorma, dan secara umum norma-norma tersebut menjadi kerangka acuan dalam bersikap dan bertingkah laku agar sejalan dengan keyakinan agama yang dianut. Segala bentuk simbolsimbol keagamaan, mukjizat, magis maupun upacara ritual sangat berperan dalam proses pembentukan sistem nilai dalam diri seseorang. Setelah terbentuk, maka seseorang secara serta merta mampu menggunakan sistem nilai dalam memahami, mengevaluasi serta menafsirkan situasi dan pengalaman, artinya bahwa sistem nilai yang dimilikinya terwujud dalam bentuk norma-norma tentang bagaimana sikap diri, dan peran agama dalam memberi pengaruhnya yang paling penting adalah sebagai pembentuk kata hati (conscience). Shaftesbury mengasumsikan kata hati sebagai suatu rasa moral di dalam diri manusia berupa rasa benar dan salah (Jalaluddin, 2012: 318-320), yang dalam ajaran agama Hindu disebut dengan wiweka, yaitu kemampuan untuk membedakan antara yang benar dan salah.

Agama dalam kehidupan masyarakat berfungsi sebagai motivasi dan etos masyarakat, karena menurut Kuper dan M. G. Smith, solidaritas dan konsensus dari suatu masyarakat dianggap sebagai unsur budaya yang digunakan sebagai pedoman hidup sehari-hari bersumber dari ajaran suatu agama. Thomas E O'dea mengatakan bahwa 
solidaritas menjadi dasar terbentuknya organisasi dalam masyarakat, sedangkan konsensus merupakan persetujuan bersama terhadap nilainilai dan norma-norma yang memberikan arah dan makna bagi kehidupan kelompok (Jalaluddin, 2012: 322-323).

Tobroni dan Arifin (1994) mengungkapkan bahwa ajaran teologis setiap agama mengandung misi suci yang menyerukan kepada seluruh umat manusia mencapai realitas tertinggi melalui kesadaran transedental yang dimiliki. Dalam konteks kemanusiaan setiap agama mengajarkan komitmen kebersamaan dalam hidup dengan keharusan mengesampingkan unsur-unsur primordialisme yang menyelimuti kehidupan manusia. Oleh karena itu, setiap agama memiliki konsep yang sama tentang kesetaraan umat manusia untuk mencapai kehidupan yang baik tanpa adanya sekat dalam keberagaman (Nurfitasari, 2014: 3).

Berdasarkan pemaparan tersebut, maka agama adalah kekuatan penting bagi kehidupan manusia. Oleh karena itu, agama justru harus ditempatkan secara proporsional dalam konteksnya. Selaras dengan pendapat Abraham Haschel yang mengatakan bahwa "agama bukanlah pulau dalam dirinya". Kimball menegaskan bahwa sekarang agama harus dipahami dan ditafsirkan dalam konteks pluralisme global. Kenyataan plural dunia inilah yang harus dijadikan sebagai titik tolak dalam memahami posisi agama dewasa ini (Na'im dan Sauqi, 2010: 19).

Pluralitas agama merupakan realitas yang tidak dapat dihindari dalam kehidupan masyarakat.
Banyak jalan menuju Tuhan, sebagaimana tertuang di dalam pustaka Bhagavad Gītā IV. 11 yang menyatakan bahwa "bagaimanapun (jalan) manusia mendekati-Ku, Aku terima wahai Arjuna. Manusia mengikuti jalan-Ku pada segala jalan" (Pudja, 1999: 112). Selain itu, dalam konteks bermasyarakat juga tidak dapat dihindari antara agama identitas (formalitas) dan agama kebenaran. Agama identitas akan senantiasa melahirkan pertentangan bahkan konflik, sedangkan agama kebenaran akan senantiasa melahirkan kasih sayang dan kedamaian.

Ketika kita berbicara mengenai terwujudnya kerukunan dalam kehidupan masyarakat, artinya kita telah berasumsi bahwa terdapat suatu kemungkinan untuk hidup berdampingan dalam satu landasan bersama. Landasan bersama itu akan terwujud apabila adanya titik temu diantara agamaagama. Kenapa harus ada titik temu agama-agama? Karena kerukunan itu merupakan sikap saling pengertian dan saling menghargai, yang mengarah pada titik temu pada hal-hal yang prinsipil.

Mewujudkan kerukunan dalam menjalani kehidupan beragama merupakan salah satu usaha untuk menciptakan kebaikan hubungan antar sesama manusia yang berbeda keyakinan, sehingga setiap golongan antar sesama manusia yang berbeda agama dapat melaksanakan kewajibannya sesuai dengan kepercayaannya masing-masing. Kerukunan yang berpegang kepada ajaran masingmasing agama dapat menjadikan setiap golongan antar sesama manusia yang memiliki keyakinan berbeda sebagai golongan yang terbuka. Golongan yang bersifat terbuka akan memudahkan terwujudnya komunikasi atau hubungan yang 
baik, apabila anggota dari golongan atau antar golongan agama yang berbeda telah melakukan komunikasi atau hubungan yang baik maka bukan tidak mungkin dapat mengembangkan hubungan tersebut ke dalam berbagai bentuk kerjasama dalam menjalani kehidupan, baik bermasyarakat maupun bernegara.

Dialog antar agama (keterbukaan / inklusif) untuk menghadapi berbagai kemungkinan perubahan di masa depan harusnya lebih diutamakan daripada mengklaim kebenaran “tunggal” (ketertutupan / eksklusif). Namun, terkadang orang-orang memang tidak sadar dan kurang mau berusaha menyadari bahwa semua penampakan yang tampaknya berbeda merupakan kesatuan dari entitas yang tunggal sebagai ultimate reality. Apabila diamati secara seksama, sesungguhnya pada tataran esoterik semua agama sama-sama mengakui adanya entitas tertinggi yang sempurna (The Perfect Supreme Being), Tunggal, dan bersifat abadi.

Ketunggalan dan kemutlakan hanya ada di dalam ajaran Tuhan sendiri. Dengan demikian, Zat Yang Tak Terbatas, Yang Utama, dan Yang Abadi hanyalah Tuhan yang Maha Esa. Jadi, semua bentuk atau perwujudan tidak dapat menganggap dirinya sebagai pemilik satu-satunya kebenaran yang mutlak. Dengan demikian dalam konteksnya seharusnya tidak ada lagi argumen yang menyatakan bahwa ada agama yang lebih tinggi atau sempurna dari agama yang lainnya. Semua bentuk-bentuk agama adalah sederajat, karena semuanya sedang mewadahi Kemahabenaran dan Kemahamutlakan Tuhan (Bahri, 2011: 21).
Berdasarkan pemaparan di atas, maka konsep esoterisme yang terdapat di dalam teks Tutur Jatiswara menarik untuk dianalisis dalam upaya membangun kerukunan hidup dengan paradigma berpikir inklusif di tengah keberagaman latar belakang masyarakat. Dengan pemaparan konsep esoterisme yang terdapat di dalam teks Tutur Jatiswara diharapkan dapat menjadi "obat penawar" gesekan-gesekan ataupun konflik, dan peluang terjadinya radikalisasi keagamaanpun semakin berkurang, sehingga mampu membangun kehidupan yang damai, harmonis, dan penuh kasih sayang.

\section{PEMBAHASAN}

\subsection{Kerukunan}

Kata kerukunan berasal dari kata dasar rukun, kemudian mendapatkan awalan ke- dan akhiran -an. Kata rukun, dalam Kamus Besar Bahasa Indonesia berarti (1) baik dan damai, tidak bertengkar (tentang pertalian persahabatan dan sebagainya); (2) bersatu hati, bersepakat (DEPDIKNAS, 2012: 1187). Secara umum kerukunan dapat diartikan sebagai suatu keadaan di mana tercipta suatu keseimbangan sosial dalam masyarakat atau suatu keadaan / situasi bebas konflik. Bila ditinjau lebih jauh terutama bila dilihat dari kata dasarnya 'rukun', maka kerukunan bukan hanya sebagai suatu situasi atau kondisi semata tetapi kerukunan lebih mencerminkan suatu relasi yang intim antar individu ataupun kelompok dalam suatu tatanan kehidupan bermasyarakat atau beragama (fajriaha.blogspot.com).

Kerukunan sering diartikan sebagai kondisi hidup dan kehidupan yang mencerminkan 
suasana damai, tertib, tentram, sejahtera, hormat menghormati, harga menghargai, tenggang rasa, gotong royong sesuai dengan ajaran agama dan kepribadian pancasila (Depag RI, 1997: 8 \& 20).

Menurut Syaukani (2008: 5), kata kerukunan berasal dari bahasa arab ruknun, kata jamaknya adalah arkan yang berarti asas, dasar atau pondasi (arti generiknya). Dalam bahasa Indonesia arti rukun ialah:

1. Rukun (nominal), berarti: Sesuatu yang harus di penuhi untuk sahnya pekerjaan, seperti tidak sahnya manusia dalam sembahyang yang tidak cukup syarat, dan rukunnya asas, yang berarti dasar atau sendi: semuanya terlaksana dengan baik tidak menyimpang dari rukunnya agama.

2. Rukun (ajektif) berarti: Baik dan damai tidak bertentangan: hendaknya kita hidup rukun dengan tetangga, bersatu hati, sepakat. Merukunkan berarti mendamaikan, menjadikan bersatu hati. Kerukunan berarti perihal hidup rukun, rasa rukun, kesepakatan: kerukunan hidup bersama.

Kerukunan berarti sepakat dalam perbedaan-perbedaan yang ada dan menjadikan perbedaan-perbedaan itu sebagai titik tolak untuk membina kehidupan sosial yang saling pengertian serta menerima dengan ketulusan hati yang penuh keikhlasan. Kerukunan merupakan kondisi dan proses tercipta dan terpeliharannya pola-pola interaksi yang beragam diantara unitunit yang otonom. Kerukunan mencerminkan hubungan timbal balik yang ditandai oleh sikap saling menerima, saling mempercayai, saling menghormati dan menghargai, serta sikap saling memaknai kebersamaan (Lubis, 2005: 7-8). Oleh karena itu, yang dimaksud dengan kerukunan adalah hidup damai dan tentram dalam menjalani kehidupan sosial, saling toleransi antara masyarakat yang satu dengan masyarakat yang lainnya, baik yang seagama maupun beda agama, kesediaan untuk menerima adanya perbedaan keyakinan dengan orang atau kelompok lain, dan membiarkan orang lain untuk mengamalkan ajaran yang diyakini oleh masing-masing masyarakat, serta kemampuan untuk menerima adanya perbedaan.

\subsection{Teks Tutur Jatiswara}

Teks merupakan suatu susunan kata-kata yang mengandung makna atau pesan yang ingin disampaikan kepada pembaca atau pendengar. Teks dapat berbentuk tulisan maupun lisan. Menurut Cika (2005: 5), teks merupakan ide atau gagasan yang termuat dalam naskah. Dalam Kamus Besar Bahasa Indonesia, teks adalah: (1) naskah yang berupa kata-kata asli dari pengarang; kutipan dari kitab suci untuk pangkal ajaran atau alasan; bahan tertulis untuk dasar memberikan pelajaran, berpidato, dan sebagainya. (2) wacana tertulis (DEPDIKNAS, 2012: 1442).

Luxemburg (1992: 86) (dalam pusatbahasaalazhar.wordpress.com) mendefinisikan teks sebagai ungkapan bahasa yang menurut isi, sintaksis, dan pragmatik merupakan suatu kesatuan. Isi berkaitan dengan konten dari sebuah teks. Teks yang baik harus mengungkapkan gagasan-gagasan yang ada dalam kehidupan. Gagasan-gagasan tersebut dituangkan dalam 
bentuk bahasa yang berupa penceritaan atau untaian kata-kata. Isi dalam teks berkaitan dengan semantik. Semantik sangat berkaitan dengan makna. Isi dalam teks adalah maknamakna yang disampaikan pengarang, baik secara terang-terangan, lugas, jelas, maupun tersembunyi melalui simbol-simbol. Secara sintaksis sebuah teks harus memperlihatkan pertautan. Pertautan itu akan tampak apabila unsur-unsur dalam tatabahasa yang berfungsi sebagai penunjuk (konjungsi) secara konsisten dipergunakan. Pragmatik berkaitan dengan situasi atau keadaan bahasa yang digunakan dalam keadaan tertentu. Pragmatik bertalian dengan bagaimana bahasa dipergunakan dalam suatu konteks sosial tertentu; teks merupakan suatu kesatuan bilamana ungkapan bahasa oleh para peserta komunikasi dialami sebagai suatu kesatuan yang bulat. Makna kesatuan bulat mengarah pada keutuhan dari sebuah teks.

Kata tutur dalam Kamus Jawa KunaIndonesia berarti ingatan, kenang-kenangan, kesadaran; lubuk jiwa makhluk yang paling dalam, "budi yang dalam" (tempat persatuan dengan Yang Mutlak); tradisi suci, smrti (sebagai lawan śruti), teks berisi doktrin religi, doktrin religi (Zoetmulder dan Robson, 2011: 1306).

Kata jatiswara dalam Kamus Jawa KunaIndonesia berasal dari kata jati dan swara. Kata jati yang pertama berarti kelahiran, bentuk eksistensi yang ditentukan oleh kelahiran; derajat, kasta, keluarga, bangsa; status sejati atau asli dari sesuatu; senyatanya, kondisi sebenarnya dari itu; jujur, dapat dipercaya, berkata atau mengatakan kebenaran. Kedua, bunga melati (yasminum grandiflorum). Ketiga, pohon jati. Keempat, rambut terpilih. Kelima, pertapa perempuan (Zoetmulder dan Robson, 2011: 416-417). Dan kata swara berarti bunyi, suara; huruf hidup; nyanyian (Zoetmulder dan Robson, 2011: 1169).

Teks Tutur Jatiswara merupakan sebuah lontar tutur yang pada pokoknya menguraikan tentang nasehat seorang ayah (orang tua) kepada anaknya agar selalu patuh dan bertingkah laku yang baik sesuai dengan petunjuk yang tersurat dan tersirat dalam sastra-sastra agama. Tutur Jatiswara merupakan salah satu jenis lontar tutur yang nampaknya masih relatif muda melihat lontar ini dibuat di Bali dengan mempergunakan bahasa Bali.

\subsection{Esoterisme, Perenialisme dan Pluralisme Keagamaan}

Thoha (2012: 51) menyatakan bahwa trentren pluralisme agama dapat diklasifikasikan secara umum ke dalam empat kategori yaitu:

1. Tren Humanisme Sekuler (Secular Humanism) yakni tren yang dibangun atas dua konsep utama dalam mewujudkan koeksistensi damai antar agama; sentralitas manusia sebagai subyek dan obyek serta konsep sekulerisme. Humanisme sekuler pada dasarnya bercirikan antroposentris, yakni menganggap manusia sebagai titik sentral kosmos (centre of cosmos). Sentralitas manusia dalam prinsip dan tujuannya merupakan ciri paling khas dari revolusi intelektual dan kultural pada zaman modern ini. 
2. Tren Teologi Global (Global Theology), yang mengacu pada konsepsi agama yang diusung oleh Wilfred Cantwell Smith dan hipotesis transformasi pemusatan diri menuju pemusatan yang nyata (the real) yang dipropagandakan oleh John Hick. Pengaruh globalisasi dewasa ini dalam mengubah kehidupan manusia dengan segala aspeknya sangat luar biasa kompleksnya, di luar apa yang dibayangkan sebelumnya. Hal ini dapat menyebabkan lunturnya (bahkan lenyapnya) jati diri dan nilai-nilai kultur dan budaya.

3. Tren Sinkretisme (Syncretism),yang diwakili oleh gerakan masyarakat ketuhanan (brahma samaj) dan masyarakat teosofi (theosophical society) yang didirikan pada tahun 1875 di New York City. Tren ini merupakan kecenderungan pemikiran yang berusaha mencampur dan merekonsiliasikan berbagai unsur berbeda-beda yang diseleksi dari berbagai agama dan tradisi ke dalam salah satu agama yang ada.

4. Tren Hikmah Abadi (Perennial Philosopy), tren ini merupakan pemikiran baru di mana sosoknya belum mengkristal dan terlihat secara konkret, kecuali kira-kira pada dua dasawarsa dari abad ke-20 yang lalu. Prinsip-prinsip dasar dalam tren hikmah abadi dapat ditemukan dalam legenda dan mitos kuno yang berkembang dalam masyarakat primitif diseluruh dunia. Dan bentuk-bentuknya yang lebih maju terdapat hampir di setiap agama besar di dunia.

Mengacu pada empat tren diatas, pada dasarnya pluralisme ingin tampil sebagai klaim kebenaran (truth claim) yang humanis, ramah, santun, toleran, cerdas, mencerahkan, demokratis dan menjanjikan, sebagaimana yang dinyatakan oleh John Hick bahwa semua agama yang teistik maupun non-teistik dianggap sebagai jalan yang mampu memberi keselamatan, kebebasan, dan pencerahan. Jadi, dapat dikatakan bahwa keempat tren tersebut masing-masing memiliki dasar ideologis dan teoritis yang berbeda-beda. Namun, dalam pembahasan ini tren Hikmah Abadi (Perennial Philosophy / Filsafat Perennial) akan diuraikan lebih detail.

Secara etimologi, perennial berasal dari bahasa Latin perennis yang berarti kekal, selamalamanya atau abadi. Schuon dalam Amin (2009: 8-10) memandang bahwa Filsafat Perennial merupakan sarana untuk membangkitkan doktrin primordial. Pertama, semua doktrin berkenaan dengan Realitas Ultim agama, mistik, filsafat, di mana selalu memuat sesuatu yang sama yang justru tampak sebagai intinya dan melampaui batas-batas lokal dan temporal. Memang, dalam setiap agama atau tradisi terdapat doktrin-doktrin primordial dan universal, namun dalam sejarah kemanusiaan, muncul dalam bentuk yang beragam. Kedua, Schuon memperlihatkan kaitan seluruh eksistensi yang ada di alam semesta dengan Realitas Mutlak. Pengetahuan ini ada dalam diri manusia yang hanya dapat dicapai dengan intellect. Dalam karya Plotinus The six Enneads; intellect dimaknai sebagai ungkapan lain dari soul atau spirit. Schuon juga telah menunjukkan inter-relasi antara isi dan bentuk ungkapan dalam doktrin-doktrin metafisika dan agama perspektif Filsafat Perennial, di mana seluruhnya dilihat dari sudut pandang metafisika murni dan makrifat 
atau esoterisme dalam pengertian yang paling universal. Ketiga, Perennialisme secara ontologis merupakan pengetahuan yang selalu ada dan akan senantiasa ada, sekaligus bersifat universal. "Ada" dimaksudkan di sini adalah sesuatu yang bersifat eksistensial dan berkaitan erat dengan prinsipprinsip universal. Pengetahuan ini hanya bisa dicapai dengan intellect, dan pengetahuan ini ada dalam jantung semua agama atau tradisi. Intellect tidak dapat dikacaukan oleh rasio. Intellect bersifat Ilahiyah dan mampu mengetahui Tuhan, sekaligus akses ke semua manusia, sehingga manusia menyadari keberadaannya.

Sayyed Hossein Nasr mengatakan bahwa filsafat perennial adalah pengetahuan yang selalu ada dan akan ada yang bersifat universal. "Ada" yang dimaksud adalah berada pada setiap zaman dan setiap tempat karena prinsipnya yang universal. Pengetahuan yang diperoleh melalui intelek ini terdapat dalam inti semua agama dan tradisi. Realisasi dan pencapaiannya hanya mungkin dilakukan melalui metode-metode, ritusritus, simbol-simbol, gambar-gambar dan saranasarana lainnya yang dikuduskan oleh perintah suci dari surga (heaven) atau asal Ilahiah (divine origin) yang menciptakan setiap tradisi (Kuswanjono, 2006: 21-22).

Agostino Steuco (1497-1548) mengatakan bahwa prinsip tunggal dari segala sesuatu yang satu dan selalu sama dalam pengetahuan semua manusia. Keunggulan perennialis terletak pada keyakinannya akan adanya satu hikmah tunggal yang dapat diketahui semua manusia. Dalam konteks sejarah, Steuco mengatakan bahwa sejarah berjalan seperti perjalanan waktu, tidak mengenal zaman kegelapan maupun zaman kebangkitan. Hanya ada Kesejatian Tunggal yang mencakup semua periode sejarah yang akan ditemukan oleh mereka yang mencarinya (Kuswanjono, 2006: 18).

Hidayat dan Nafis sebagaimana dikutip Donder (2009: 513-514) mengungkapkan bahwa istilah perennial biasanya muncul dalam wacana filsafat agama di mana agenda yang dibicarakan adalah pertama, tentang Tuhan, wujud yang absolut, sumber dari segala wujud. Tuhan Yang Maha Besar adalah satu, sehingga semua agama yang muncul dari Yang Satu, pada prinsipnya sama karena datang dari sumber yang sama. Kedua, filsafat perennial ingin membahas fenomena pluralisme agama secara kritis dan kontemplatif. Agama dalam konteks historis selalu hadir dalam formatnya yang pluralistik, maka setiap agama memiliki kesamaan dengan yang lainnya, tetapi sekaligus juga memiliki kekhasan sehingga berbeda dari yang lainnya. Ketiga, filsafat perennial berusaha menelusuri akar-akar kesadaran religiusitas seseorang atau kelompok melalui simbol-simbol, ritus serta pengalaman keberagamaan.

Dari uraian tersebut, dapat dikatakan bahwa filsafat Perennial (Perennial Philosophy) merupakan filsafat yang dipandang mampu menjelaskan segala kejadian yang bersifat hakiki, menyangkut kearifan yang diperlukan dalam menjalankan hidup yang benar yang rupanya menjadi hakikat dari seluruh agama-agama dan tradisi-tradisi besar spiritualitas manusia. Filsafat Perennial selalu membicarakan tentang adanya "Yang Suci" (The Sacred) atau "Yang Satu" (The One) dalam seluruh manifestasinya, seperti dalam agama, filsafat, sains, dan seni (Hidayat dan Nafis, 2003: 10). 
Tradisi merupakan kebalikan dari modernisme dan sekulerisme. Asas tradisional inilah yang mengantarkan kaum tradisionalis kepada satu kepercayaan berdasarkan kesepakatan para tetua atau pemuka dalam menetapkan suatu hukum-hukum dalam agama, " bahwa semua agama, yang hidup maupun yang mati merupakan diferrent theopanies of the same Truth (manifestasi-manifestasi dan bentuk-bentuk penjelmaan yang beragam dari hakikat yang tunggal) (Thoha, 2012: 112).

Semua itu menunjukkan bahwa betapa krusialnya tradisi dan pandangan tradisional serta sentralnya filsafat Perennial. Sehingga menurut kaum tradisionalis perlu dihidupkan kembali untuk melakukan tugas suci, yaitu menyelamatkan umat manusia dari krisis dunia modern. Filsafat Perennial muncul sebagai akibat langsung dari sikap permusuhan dan kebencian akal modern "yang tercerahkan" terhadap segala sesuatu yang sakral, serta kegagalannya memahami "Kebenaran" (the Truth) dan "Hakikat" (the Reality), termasuk hakikat pluralitas keagamaan dengan pemahaman yang tepat, benar dan integral (Hidayat dan Nafis, 2003: 113).

Berdasarkan pandangan tersebut, agama-agama yang menurut kaum tradisionalis merupakan salah satu dari tiga wujud sosok utama penjelmaan Zat yang Absolut (grand theopanies of the Absolute), mempunyai dua realitas atau hakikat, yaitu esoteric dan exoteric; atau substansi (substance) dan aksiden (accident); atau esensi (essence) dan bentuk (form); atau batin (inward) dan lahir (outward) (Hidayat dan Nafis, 2003: 114).

Kata esoteric, secara etimologi berasal dari bahasa Yunani esoteros, lalu menjadi esoterikos, berasal dari kata dasar 'eso', yang artinya di da- lam atau suatu hal yang bersifat batin bahkan mistik. Dictionary of philosophy menjelaskan bahwa kata esoteric (Bahasa Yunani, esoterikos) bermakna ritual, doktrin atau puasa. Istilah ini ditemukan pada catatan dialog Plato, Alcibiades sekitar tahun 390 SM. Ia menggunakan kata 'ta eso' yang berarti sesuatu yang ada di dalam. Penggunaannya sebagai kata sifat yang paling tua ditemukan pada catatan Lucian dari Samosata (125-180), seorang ahli retorika dan sastrawan Romawi, The Auction of the Philosophical Schools, yang ditulis sekitar tahun 166 M (Bahri, 2011: 16). Dalam diskursus filsafat perennial, esoterisme adalah dimensi dalam atau inti agama. Oleh karena itu, Frithjof Schuon meyakini bahwa kesatuan agama-agama ada secara kukuh pada dimensi esoterik. Kesatuan jalan, kesatuan tujuan, dan maksud, kesatuan esensi, dan makna sejatinya ada, nyata, dan disadari serta dirasakan oleh para pemeluk agama yang berbeda-beda. Oleh karena itu, harus dipahami bahwa pada level eksoterik tidak harus selalu terjadi perbedaan dan pertentangan, karena terdapat nilai-nilai atau ajaran universal yang mempertemukan dan menyatukan agama-agama walaupun bukan pada wilayah transenden. Ajaran-ajaran mulia tentang cinta kasih, kebaikan, kejujuran, kesabaran, kesederhanaan, solidaritas sosial, dan lain-lain yang semakna sesungguhnya memberi kesadaran kepada para penganut agama-agama bahwa titik temu dan kesatuan itu niscaya pada level yang eksoterik, sebab semua berasal dari Tuhan yang sama (Hidayat dan Nafis, 2003: 344).

\subsection{Perennialisme dan Teks Tutur Jatiswara}

Dewasa ini manusia semakin dihadapkan pada satu masa yang disebut sebagai zaman 
pascamodern yang mana pluralisme telah menjadi kenyataan yang tidak dapat ditolak. Setiap agama akan bertemu dengan agama-agama lainnya, sehingga harus mendefinisikan bahkan secara teologis dan metafisik bagaimana hubungan dirinya dengan agama lain, yang tidak bisa lagi secara naif diberikan label 'kafir', 'mengalami penyelewengan', 'tidak lebih sempurna', 'lebih rendah', dan sebagainya (Hidayat dan Nafis dalam Donder, 2009: 512). Oleh karena itulah sangat penting adanya titik temu secara teologis, yang dikenal dengan sebutan perennialisme. Perennialisme sebagaimana diungkapkan oleh Leibniz merupakan metafisika yang mengakui realitas Ilahi yang substansial bagi dunia bendabenda, hidup dan pikiran; merupakan psikologi yang menemukan sesuatu yang sama di dalam jiwa dan bahkan identik dengan realitas Ilahi; merupakan etika yang menempatkan tujuan akhir manusia pada pengetahuan tentang "dasar" yang imanen maupun transenden dari segala yang ada (Huxley dalam Kuswanjono, 2006: 10).

Perennialisme mempunyai perhatian utama pada Yang Satu, yaitu realitas ketuhanan (Huxley dalam Kuswanjono, 2006: 11). Perennialisme berusaha menemukan sistem-sistem pemikiran pada masyarakat untuk memperkuat argumen bahwa pemahaman ketuhanan adalah bersifat universal pada seluruh umat manusia. Teks Tutur Jatiswara menguraikan sebagai berikut:

Sakañcan ané idup di jagaté makějang pada ngělah adan, upama maṇuṣa kaadanin I Tampul, I Témbok, I Séndi wiadin lénan. Buron kaadanin sampi, jaran, kébo miwah ané lénan.
Terjemahannya:

Segala yang hidup di dunia semua mempunyai nama, umpama manusia diberi nama I Tampul, I Tembok, I Sendi, dan lain sebagainya. Binatang diberi nama sapi, kuda, kerbau dan lain sebagainya.

Kutipan teks Tutur Jatiswara di atas menjelaskan bahwa pada ranah eksoterik sangat terlihat dengan jelas perbedaannya masingmasing. Namun apabila manusia naik pada ranah esoterik, maka akan melihat pertemuan diantara perbedaan dalam satu titik yang sama. Hal ini sejalan dengan keyakinan manusia bahwa Tuhan sebagai sumber segalanya, jadi sudah tentu kebenaran pun bersumber pada yang satu pula. Hindu mengajarkan kesatuan umat manusia, karena sesungguhnya adalah bersaudara (vasudaiva kutumbhakam) dan tidak ada perbedaan diantara mereka dalam tujuan, sama halnya seperti ketika umat Hindu bersembahyang di Pura Besakih. Ketika umat Hindu sembahyang ke Pura Besakih diawali dengan sembahyang di Pura Padharman masing-masing, di sana nampak sekali adanya tembok-tembok pemisah antara kelompok yang satu dengan kelompok yang lainnya, namun ketika beranjak sembahyang ke Pura Penataran Agung semua kelompok berkumpul pada satu ruang yang sama, yaitu di hadapan Padma Tiga. Ini menggambarkan bagaimana kesatuan serta kesejajaran terwujudkan. Hal senada juga digambarkan oleh Frithjof Schuon dalam suatu sketsa hubungan atau titik pertemuan masingmasing jalan dalam menuju Tuhan, sebagai berikut: 


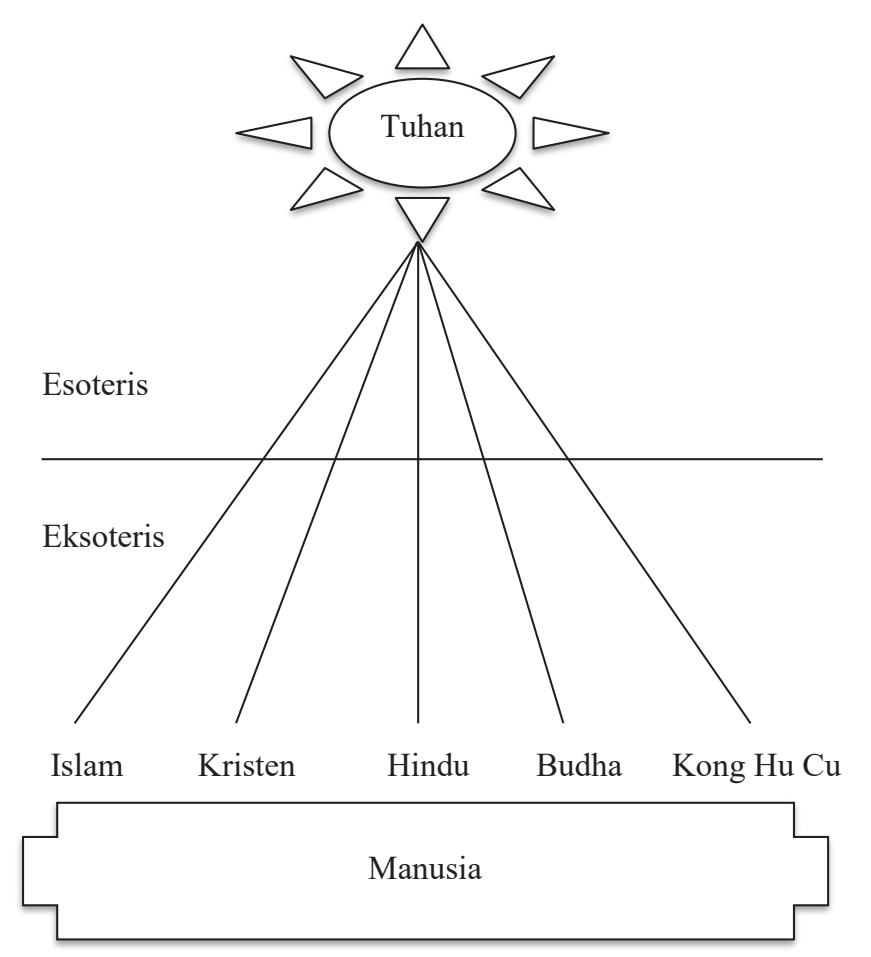

Bagan 1

Sketsa Frithjof Schuon tentang Titik Temu Agama-Agama

Kesadaran eksoterik dan esoterik dapat ditemukan melalui pengalaman mencari Tuhan dengan jalan mengharmoniskan diri, baik dengan Tuhan, manusia, dan alam lingkungan. Manusia sejati yang telah mencapai "kesadaran" dan telah memahami hakekat dirinya tidak akan memikirkan perbedaan-perbedaan yang ada dalam bentuk apapun, karena sesungguhnya tidak ada yang berbeda di dunia ini.

Menurut Schuon, setiap proses pencarian dan perjalanan seseorang menuju Tuhan adalah sama, yakni benar-benar menyadari kedudukannya sebagai makhluk Tuhan yang memiliki kewajiban melaksanakan penyembahan kepada-Nya, karena jika tidak, maka agama sebagai jalan menuju Tuhan akan berbeda dengan agama yang lainnya (Harahap, 2011: 75-76).
Puspadanta dalam Mahimnahstotra ayat 8 mengatakan ketiga Veda, Sāmkhya, Yoga, Pasupatimata dan Vaisnava sebagai kebhinekaan garis pemikiran manusia karena selera mereka yang berbeda, menganggap satu atau yang lainnya sebagai yang terbaik, dan konsekuensinya adalah mengambil jalan pilihan entah itu lurus atau bengkok, langsung atau tak langsung. Tetapi, O, Śiva! Kau sendiri agar didekati oleh semua, seperti samudera di dalam hal air (Suamba, 2003: 84). Menurut Schuon, bila tidak ada persamaan pada agama-agama, kita tidak akan menyebutnya dengan nama yang sama 'agama'. Bila tidak ada perbedaan diantaranya, kita pun tidak akan menyebutnya dengan kata majemuk 'agama-agama' (Smith dalam Harahap, 2011: 71). Hal ini merupakan penghargaan kepada eksistensi manusia dengan segala perbedaannya.

Perbedaan jalan yang dapat ditempuh merupakan bentuk keindahan tersendiri. Realisasi bisa diraih oleh siapa saja dengan disiplin diri, mengikuti jalan kebenaran, pengetahuan dan cinta kasih. Upaya-upaya tersebut hendaknya dilakukan dengan sadar dan komitmen diri karena banyak rintangan yang dihadapi. Jalan yang dianjurkan untuk merealisasikan kebenaran tersebut bermacam-macam, masing-masing menganjurkan caranya tersendiri. Ada yang menganjurkan dengan melakukan kewajiban atau kerja, ada dengan cara penyerahan diri bahkan pengorbanan, dengan cara pengetahuan, maupun dengan perpaduan. Bhagavan Sri Sathya Sai Baba dalam Ranvir Singh, sebagaimana dikutip Donder (2009: 23) menyampaikan bahwa: 
Agama ada banyak, tetapi memiliki satu tujuan, Permata-permata itu banyak, tetapi emas itu hanya satu,

Bintang-bintang itu banyak, tetapi langit itu satu,

Sapi-sapi itu banyak, tetapi susu adalah satu, Makhluk itu banyak, tetapi nafas itu satu,

Bangsa-bangsa itu banyak, tetapi bumi itu satu,

Bunga-bunga itu banyak, tetapi pemujaan adalah satu.

Hal ini berarti bahwa ada yang satu (tad evam) berdiri di belakang semua fenomena alam dengan berbagai nama. Rabindranath Tagore dalam Suamba (2003: 92) mengatakan asimilasi dari begitu banyak kebudayaan dunia telah memberikan kontribusi di dalam suatu sintesa brilien arus pemikiran dunia:

"Datanglah, O orang-orang Arya dan Non Arya Hindu dan Muslim

Datnglah, O orang-orang Inggris dan engkau orang-orang Kristiani

Datanglah, O para Brahmana

Sucikanlah pikiranmu dan berpegangan tanganlah semua

Datanglah, O orang-orang tertindas

Dan biarlah hilang semua beban penghinaanmu

Jangan kau tangguhkan, datanglah kau semuanya

Untuk menghiasi ibu pertiwi di pantai Bharata

Dimana manusia semua ras datang bersamasama” (Gitanjali).
Donder (2009: 24) menguraikan bahwa agama bukanlah konsep yang membatasi, tetapi ditujukan untuk mengembangkan keperibadian manusia dan memberi pedoman dasar untuk menjalankan kehidupan dengan baik serta mengeluarkan atau mengejawantahkan rasa kemanusiaan yang ada dalam diri manusia dan memungkinkannya untuk hidup dalam harmoni dengan sesamanya. Hal inilah yang seharusnya dipahami dan dijadikan pedoman oleh semua umat manusia untuk mewujudkan kesatuan di dalam perbedaan. Di dalam teks Tutur Jatiswara disebutkan sebagai berikut:

Anaké nyidayang ninggalang gěděg saking mapitutur, buka solah lélipiné ninggalang kulěsné, tusing buin ngaliputin nganggon kulěsné, madan lěwihing ajñana, pagěh kaadanin maṇuṣa.

Terjemahannya:

Orang yang mampu meninggalkan marah dengan nasehat, seperti halnya ular yang meninggalkan kulit arinya, tidak lagi dipengaruhi oleh kulit luarnya, disebut keutamaan pikiran, kukuh disebut manusia.

Berdasarkan kutipan di atas, tersirat suatu pengertian bahwa setiap orang hendaknya mampu meninggalkan amarah, kebencian, kebohongan, iri hati, serta ketidakbenaran lainnya dengan mengamalkan dharma, baik dalam pikiran, perkataan maupun perbuatan. Tidak boleh memvonis hanya dengan melihat kulit luar atau case-nya saja dan hanya dengan menggunakan 
satu sudut pandang, karena dewasa ini tidak jarang kenampakan wujud sering 'menipu', ibaratnya seperti Rāvaṇa yang menyamar menjadi seorang brahmana agar bisa menculik Devi Sìtā dalam kisah Rāmāyaṇa pada bagian Āraṇyakāṇḍa. Orang yang telah mampu meninggalkan semua hal itu sebagaimana disebutkan di atas, disebut sebagai manusia yang utama atau sempurna (maryada purusottama).

Keanekaragaman ajaran hendaknya dipahami sebagai wujud kebenaran yang sama, karena sesungguhnya tidak ada satu ajaranpun yang mengajarkan hal-hal yang tidak benar, semua pasti mengajarkan tentang kebajikan. Dengan kebajikan (kejujuran, tidak saling menyakiti, persaudaraan, dan sebagainya) merupakan cara terbaik untuk mendapatkan rasa aman dan adil dalam kehidupan sosial. Dengan adanya rasa aman dan adil yang tercipta, kerukunan, keharmonisan, serta kedamaian pun akan menjadi satu kesatuan di dalamnya. Teks Tutur Jatiswara menguraikan sebagai berikut:

Yan munggwing anaké madan adil, tusing binayanga awakné těkén awak anaké èlénan yuadin těkén sarwa mahuripé.

Terjemahannya:

Orang disebut adil, tidak dibedakan dirinya dengan orang lain serta terhadap makhluk hidup lainnya.

Kutipan teks Tutur Jatiswara di atas mengandung makna, bahwa pemahaman dan kesadaran akan hakekat kehidupan bagi setiap manusia bertujuan untuk mengangkat jati diri manusia yang didasarkan pada penggalian pengetahuan agar bisa menjadi 'lentera' dalam kehidupan masyarakat dengan memperagakan kebenaran sejati, mengajarkan kepada masyarakat mana yang baik dan mana yang jelek. Karena, ketika datang ke masyarakat dengan kebenaran yang sejati maka semua orang akan menerima dengan kehangatan, hormat dan lapang dada. Masyarakatmelupakan perbedaan-perbedaaannya. Nilai-nilai spirit tersebut dapat menjadi perekat bagi masyarakat majemuk seperti di Indonesia.

Berkaitan dengan bidang etika, kutipan teks Tutur Jatiswara tersebut mengajarkan keharusan untuk mewujudkan kerukunan, keadilan, musyawarah, menolong orang yang membutuhkan bantuan sebagai swadharma, mengembangkan kegiatan yang berguna untuk kesejahteraan masyarakat, serta larangan untuk melakukan perbuatan yang dapat merugikan maupun membahayakan orang lain. Prinsipprinsip etika tersebut dapat memperkuat hubungan antar sesama manusia serta mempersatukan perasaan sebagai dasar kebajikan yang universal yang sangat diperlukan dalam kehidupan sosial.

\section{PENUTUP}

Hakikat merupakan jalan kesatuan wujud, kesatuan maksud dan tujuan, dan kesatuan esensi sejatinya ada dan nyata, serta disadari dan dirasakan oleh para pemeluk agama yang berbeda-beda. Dengan demikian, kesatuan 
transendensi agama-agama terjadi pada level "mutlak" yaitu "kebenaran" (the Truth) dan sekaligus "riil" (the Real) yang merupakan sumber segala wahyu dan kebenaran. Kesatuan tersebut berada pada wilayah esoterik dari agama. Sedangkan perbedaan-perbedaan agama terletak pada dimensi yang eksoterik. Dengan demikian, filsafat perennial diyakini mampu memberikan solusi teo-filosofis bagi problem pluralitas agama. Kenyataan inilah yang mendasari adanya pernyataan bahwa semua agama adalah sama dalam wilayah esoterik. Tidak ada agama yang superior diantara agama yang lain, karena pada dasarnya semua agama sedang mewadahi "Kebenaran dan Kemutlakan" dari Yang Maha Esa. Hal ini sejalan dengan keyakinan manusia bahwa Tuhan sebagai sumber segalanya, jadi sudah tentu kebenaran pun bersumber pada yang satu pula. Hindu mengajarkan kesatuan umat manusia, karena sesungguhnya adalah bersaudara (vasudaiva kutumbhakam) dan tidak ada perbedaan diantara mereka dalam tujuan.

Manusia sejati yang telah mencapai "kesadaran" dan telah memahami hakekat dirinya tidak akan memikirkan perbedaan-perbedaan yang ada dalam bentuk apapun. Kesadaran esoterik ini dapat mengantarkan seseorang pada pencapaian kebajikan. Dengan kebajikan (kejujuran, tidak saling menyakiti, persaudaraan, dan sebagainya) merupakan cara terbaik untuk mendapatkan rasa aman dan adil dalam kehidupan sosial. Dengan adanya rasa aman dan adil yang tercipta, kerukunan, keharmonisan, serta kedamaian pun akan menjadi satu kesatuan di dalamnya.

\section{DAFTAR PUSTAKA}

Abdullah, M. Amin. 2009. Falsafah Kalam di Era Post Modernisme. Yogyakarta; Pustaka Pelajar.

Bahri, Media Zainul. 2011. Satu Tuhan Banyak Agama: Pandangan Sufistik Ibn'Arabi, Rumi, dan al-Jili. Bandung: Mizan.

Cika, I Wayan. 2005. Peranan Filologi dalam Pelestarian Kebudayaan Bangsa (Perspektif Ontologis, Epitemologis, dan Aksiologis). Denpasar: Universitas Udayana.

Departemen Pendidikan Nasional. 2012. Kamus Besar Bahasa Indonesia Pusat Bahasa. Jakarta: PT. Gramedia Pustaka Utama.

Depag RI. 1997. Bingkai Teologi Kerukunan Hidup Umat Beragama di Indonesia. Jakarta: Badan Penelitian dan Pengembangan Agama Proyek Peningkatan Kerukunan Umat Beragama di Indonesia. Diakses melalui digilib.uinsby.ac.id.

Donder, I Ketut. 2009. Teologi: Memasuki Gerbang Ilmu Pengetahuan Ilmiah tentang Tuhan Paradigma Sanatana Dharma. Surabaya: Paramita.

Harahap, Syahrin. 2011. Teologi Kerukunan. Jakarta : Prenada Media Group.

Hidayat, Komaruddin dan Wahyuni Nafis. 2003. Agama Masa Depan: Perspektif Filsafat Perennial, Jakarta: Gramedia Pustaka Utama. 
Jalaluddin. 2012. Psikologi Agama, Memahami Perilaku dengan Mengaplikasikan PrinsipPrinsip Psikologi. Jakarta: Rajawali Pers.

Kuswanjono, Arqom. 2006. Ketuhanan dalam Telaah Filsafat Perenial, Refleksi Pluralisme Agama di Indonesia. Yogyakarta: Badan Penerbitan Filsafat UGM.

Lubis, Ridwan. 2005. Cetak Biru Peran Agama. Jakarta: Puslitbang.

Na'im, Ngainun dan Achmad Sauqi. 2010. Pendidikan Multikultural Konsep dan Aplikasi.Yogyakarta; Ar-Ruzz Media Grup.

Nurfitasari, Diyah Ayu. 2014. “Teologi Pluralisme dalam Perspektif Pemikiran Gus Dur". (Skripsi). Semarang: Institut Agama Islam Negeri Walisongo.

Pudja, G.1999. Bhagavad Gìtā (Pañcama Veda). Surabaya : Paramita.

Shofan, Moh. 2011. Pluralisme Menyelamatkan Agama-Agama. Yogyakarta: Samudra Biru.

Dermawan, Andy. 2009. Dialektika Islam dan Multikulturalisme di Indonesia. Yogyakarta: Kurnia Kalam Semesta.

Syaukani, Imam. 2008. Kompilasi Kebijakan dan Peraturan Perundang-Undangan Kerukunan Umat Beragama. Jakarta: Puslitbang.

Suamba, I.B. Putu. 2003. Dasar-Dasar Filsafat India. Denpasar: Program Magister Ilmu Agama dan Kebudayaan UNHI Denpasar bekerjasama dengan Penerbit Widya Dharma.
Thoha, Anis Malik. 2007. Tren Pluralisme Agama: Tinjauan Kritis. Jakarta: Perspektif Kelompok Gema Insani.

Zurqoni dan Muhibat. 2011. Menggali Islam Membumikan Pendidikan: Upaya Membuka Wawasan Keislaman \& Pemberdayaan Pendidikan Islam. Yogyakarta: Ar-Ruzz Media.

Zoetmulder, J dan S.O. Robson. 2011. Kamus Jawa Kuna-Indonesia. Terjemahan oleh Darusuprapta dan Sumarti Suprayitna, Jakarta: PT. Gramedia Pustaka Utama. 